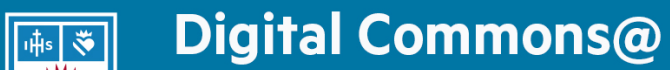

Loyola Marymount University

LMU Loyola Law School

\section{Journal of Catholic Education}

September 2015

\section{The USCCB Curriculum Framework: Origins, Questions, And A Call For Research}

Carrie J. Schroeder

Mercy High School, San Francisco

Follow this and additional works at: https://digitalcommons.Imu.edu/ce

Part of the Curriculum and Instruction Commons, Educational Leadership Commons, Other Education Commons, and the Religion Commons

\section{Recommended Citation}

Schroeder, C. J. (2015). The USCCB Curriculum Framework: Origins, Questions, And A Call For Research. Journal of Catholic Education, 19 (1). http://dx.doi.org/10.15365/joce.1901022015

This Article is brought to you for free with open access by the School of Education at Digital Commons at Loyola Marymount University and Loyola Law School. It has been accepted for publication in Journal of Catholic Education by the journal's editorial board and has been published on the web by an authorized administrator of Digital Commons at Loyola Marymount University and Loyola Law School. For more information about Digital Commons, please contact digitalcommons@lmu.edu. To contact the editorial board of Journal of Catholic Education, please email JCE@nd.edu. 


\title{
The USCCB Curriculum Framework: Origins, Questions, and A Call for Research
}

\author{
Carrie J. Schroeder, Mercy High School, San Francisco
}

The promulgation of Doctrinal Elements of a Curriculum Framework for the Development of Catechetical Materials for Young People of High School Age by the United States Conference of Catholic Bishops (USCCB) in November 2007 represented a milestone in the efforts of the U.S. bishops to monitor and shape the Religious Studies curricula of U.S. Catholic secondary schools. This article contextualizes the Framework, providing comprehensive information about its origins. With the release of the English translation of the new Catechism of the Catholic Church in 1994, the U.S. bishops launched a full-scale effort to address what they perceived to be a crisis of religious illiteracy among Catholics. Central to this effort was an attempt to ensure that all catechetical materials used in Catholic parishes, elementary and secondary schools, and other programs would be in conformity with the doctrinal content, theological approach, and language of the Catechism. When members of the USCCB found many Religious Studies textbooks commonly utilized in U.S. Catholic secondary schools to be gravely deficient both theologically and pedagogically, they began, in early 1999, to create what would become the Framework. Other relevant documents issued following the Framework's promulgation have further clarified the bishops' expectations regarding Religious Studies in U.S. Catholic secondary schools. This article addresses many of the questions about the Framework that Religious Studies teachers may have, such as those documented by Schroeder (20I3), and invites authors and researchers to subject the Framework to the rigors of empirical research.

\section{Keywords}

Religious Studies, USCCB Framerwork, U.S. Catholic secondary schools, Catechism of the Catholic Church

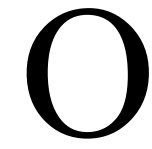

n November I4, 2007, the 22I Catholic bishops of the United States gathered for their semi-annual meeting, where they unanimously approved a document entitled Doctrinal Elements of a Curriculum

Journal of Catholic Education, Vol. I9, No. I, September 2015, 5-26. This article is licensed under a Creative Commons Attribution 3.0 International License.

doi: $10.15365 /$ joce. 1901022015 
Framework for the Development of Catechetical Materials for Young People of High School Age (United States Conference of Catholic Bishops [USCCB], 2008; hereafter, Framework). This document offered "a detailed framework for catechetical instruction for high school students" (Zapor, 2008, ๆ I) based on an eight-semester curriculum of six required courses and two electives- the latter to be chosen from among five approved courses. In the years since the Framework's official promulgation, each local bishop has exercised his authority to decide whether, how, and when to implement it in his respective diocesan territory, a situation that Filteau (20I0) has characterized as "uneven" (p. ra). Although bishops' responses to the Framework have thus far been varied, this situation may change, as alignment with the Framework becomes one of the criteria by which U.S. Catholic secondary schools are accredited. For example, beginning with the 2OII-2OI2 academic year, U.S. Catholic secondary schools seeking accreditation by the Western Catholic Educational Association (WCEA) have been evaluated with a new instrument entitled Ensuring Educational Excellence (WCEA, 2013). This instrument includes eight "Catholic Identity" standards, one of which is the following: "The school uses a Religion curriculum and instruction that is faithful to Roman Catholic Church teachings, subject to the authorization of the Local Ordinary, and otherwise meets the requirements set forth by the USCCB" (2013, p. 8). Directing the school to report "the extent to which the religion texts in use conform to the USCCB's Doctrinal Framework" (20I3, p. 2I) strongly suggests that a school seeking accreditation utilize Religious Studies ${ }^{\mathrm{I}}$ textbooks that adhere to the Framework.

In the years since the Framework's promulgation, few articles and dissertations have analyzed or critiqued this document; these include a pair of articles by O'Malley (2009) and McBride (2009), which presented divergent assessments of the Framework. A piece in the National Catholic Reporter recounted the adoption of the Framework by many U.S. dioceses (Filteau, 20Io) and offered an interview with catechetical expert Thomas Groome (Heffern, 20IO). Raiche (20IO), Tiernan (20I0), and Manning (20I2) proffered pedagogical guidance to assist teachers with the logistics of implementation. Ostasiewski's (20Io) dissertation analyzed and critiqued the Framework from both theological and pedagogical standpoints.

1 The author defines "Religious Studies" as the academic department of a U.S. Catholic secondary school offering courses in Scripture, moral theology, Church history, world religions, liturgical theology, social justice, etc. As documented by Hudson (2002), schools employ various terms to designate this department; therefore, the author considers this term synonymous with "Religion" and "Theology." 
Both Engel's (2013) and Ramey's (20I4) dissertations treated the Framework somewhat tangentially. Engel's (2013) examination of the Framerwork contextualized his catechetical and pedagogical analyses of Framework-based textbooks. Because none of the participants in Ramey's (2014) qualitative study of Religious Studies teachers was currently teaching in a diocese mandating the Framework, she theorized only that the Framework may present a future challenge for these teachers.

In schools in which the Framework has been implemented, as well as in schools facing imminent review under Ensuring Educational Excellence, Religious Studies teachers may speculate about the bishops' rationale for creating the Framework and/or the process by which this creation occurred. Neither academic journals nor popular publications have offered a detailed, comprehensive history of the Framework's development; yet, participants in Schroeder's (2013) study expressed a strong desire for such information. In this qualitative study, utilizing in-depth interviews and elements of participatory action research to detail the experiences of teachers who had taught Religious Studies both before and after the Framework's implementation, participants articulated a wide variety of questions and musings regarding the Framework's origins. One participant, Grace, expressed curiosity regarding the bishops' logic in developing the Framerwork's content: "I can't comment on their thoughts or purpose for how they organized this core curriculum and electives. I would be very interested to understand their thought processes" (2013, p. 289). Another, Rosa, theorized that the bishops were motivated by concern over people leaving the Catholic Church: "I just think they're just seeing the church shrink.... and they think this is gonna be the answer. If you understand everything about Jesus, you're gonna stay a Catholic" (2013, p. 288).

Lanie, also a participant in Schroeder's (2013) study, stated that she had sought information regarding the bishops' motives for developing the Framework and the research they conducted, if any, to inform their approach to this task. This search yielded few results, leaving her with more questions than answers. Some questions related to the bishops' rationale for promulgating the Framework:

I don't know where their mindset was. I don't know if it was coming out of fear that they're losing Catholics in the pews, and so there's less money coming in, and so "we've gotta do something," "let's tighten up the belt," or "let's go back to the Baltimore Catechism." (Schroeder, 2013, p. 289) 
Other questions related to whether the bishops consulted Religious Studies teachers in U.S. Catholic secondary schools or other professionals:

I would like to give them the benefit of the doubt, that they actually spoke to people in religious education....I'm hoping that they did....I didn't see any evidence of that. It wasn't even in their introductionthat, "this Framework developed out of conversations with...." There was none of that... There's just a lot of questions and no place to find answers. (Schroeder, 2013, pp. 289-290)

Still another of Schroeder's (2013) participants, Julia, raised numerous questions regarding what social, psychological, cultural, and ecclesial factors the bishops considered in developing the Framework. She articulated these questions at length:

Did the bishops...take time to consider psychologically where the students are and what they need? Did they consider the faith development....Did the bishops research any of [the] current educational faith formative psychological adolescent trends? Did the bishops consider, why are students leaving our Church?...Did the bishops consider the means with which students are making decisions... and how can the Framework bring them closer to the ethical and moral principles that Jesus taught us?...Is the Framework interesting to them? Is it relevant?... Did the bishops consider what are some of the most important foundational, absolute, solid principles that any student who goes through a Catholic school should leave with? And do we have the opportunity to focus on those? Those are my worries. Where are those things in the Framework?...Do we have the research to see the reasoning why the things that the bishops have chosen [for] us to teach, why we're teaching it? What's the rationale?...What really are the real goals that the bishops want? Are they articulated? Those are open ends that I feel like if we had answers to those questions, or if the bishops explained them better in the Framework, then perhaps as teachers...we'd have a better ability to connect the dots....Was it [the Framework] constructed in a manner that is going to create changes and growth in our students?.... Did they consider, from the students' perspective, what the students need... and that these students are going to grow up and choose to either stay in the Church or leave the Church? (Schroeder, 2013, pp. 290-29I) 
When invited by Schroeder (2013) to propose answers to some or all of the questions raised in those protracted remarks, Julia responded in this way:

They're rhetorical...because I don't know the answers. Maybe I haven't studied enough of the Framework, or asked the right people. But...as a teacher, when you read through the Framework, and when you receive a textbook that has the Framework in it, the underlying foundational questions are these....I don't have answers to those questions, and I think we need answers. (p. 29I)

This article offers a comprehensive history of the Framework's development from $1985^{-2007}$, as well as discussion of subsequent events since its promulgation. This information will aid Religious Studies teachers and administrators in U.S. Catholic secondary schools, particularly those in which the Framework has already been implemented or those in which adherence to the Framework will soon constitute a criterion for accreditation. Thorough, accurate information about the Framework's origins, rooted in the documentary evidence of primary sources, will help ensure that these school personnel view the Framework within its larger context; namely, the bishops' overarching concerns about the state of religious literacy and the quality of catechesis in the United States. Clear and unbiased knowledge regarding that larger, ecclesial context may form the basis for fruitful, productive dialogue about the Framework both among teachers and administrators and between school personnel and their bishops. The article will conclude by calling for empirical research that explores the Framework's impact on Religious Studies in U.S. Catholic secondary schools, research for which this article seeks to lay the groundwork.

\section{The Call for a New Catechism: Addressing Perceived Religious Illiteracy}

In October of 1985, the Extraordinary Synod of Bishops, gathered in Rome, recommended the preparation of a new universal Catechism of the Catholic Church, with work to commence the following summer. On February 2I, I990, Archbishop William Levada of Portland, Oregon-the only American among the seven bishops on the committee charged with writing the new catechism-issued an overview of the then in-progress document. He expressed profound concern for the lack of religious literacy among contemporary Catholics, postulating that such concern motivated the Synod's recommendation for a new catechism: 
One of the most popular board games of the past Christmas season was an irreverent look at Catholicism called "Is the Pope Catholic?" Despite their irreverence, board games that center on Catholic trivia seem to surface a central and disturbing fact. Families soon discover that anyone born after the I96o's cannot answer the Baltimore catechism questions that many consider part of our Catholic heritage. Neither do they remember many of the events that most of us consider central to our own experience of Catholicism. While few persons consider knowing the mysteries of the rosary recited on Monday essential to salvation, experiences like these are enough to make parents express concern about the religious education of their children.

Concern for the transmission of the faith is not uniquely parental. Nor is it only episcopal. It is an issue that comes to the fore at any national, diocesan or parish meeting of either priests or laity called to surface primary issues of concern. (I990, $9 \mathrm{I}-2$ )

Later that same year, the entire body of U.S. bishops expressed similar concern regarding the accurate transmission of Catholic doctrine through catechesis. In their Guidelines for Doctrinally Sound Catechetical Materials (United States Catholic Conference [USCC], I990), the bishops described the vast array of catechetical materials available for children, youth, and adults as potentially problematic:

Most of these materials advance and enrich the Church's catechetical mission, but their diversity and quantity present a new challenge. The faithful expect the bishops - and we recognize it as our responsibilityto assure them that these materials express the teaching of the Church as faithfully as possible. (p. 3)

In response to this perceived need for clearer guidelines regarding catechetical materials, the bishops articulated the criterion of doctrinal soundness, describing doctrinally sound materials as those which encompass "a complete and correct presentation of Church teaching, with proper attention to its organic unity" (p. 4 ) and which are readily understandable to the group of people to whom they are addressed.

Following the public promulgation of the Catechism of the Catholic Church on December 7, 1992, and in anticipation of the document's pending translation into English, Archbishop Levada hosted a symposium on the new 
Catechism in February 1994. At this event, he acknowledged that, even in the I970s, Church officials recognized the need to ground any renewal of catechesis in sound, accurate doctrine. However, he maintained that in the intervening years:

The immense shift in theological vocabulary and emphasis and the voices of dissent over church doctrines in morality and even in the meaning of the creed tended to undermine both clarity and conviction in the presentation of the teachings of the faith. (Levada, 1994, I I9)

In 1994, following the publication of the Catechism's English translation, the United States Catholic Conference (USCC) ${ }^{2}$ formed the Ad Hoc Committee to Oversee the Use of the Catechism, chaired by Archbishop Daniel Buechlein of Indianapolis, Indiana. Its objectives included overseeing the use of the Catechism in both the revision of present catechetical materials and in the development of new materials; that is, to ensure the consistency of catechetical materials with the Catechism's themes, language, and approach to doctrine. To this end, the Ad Hoc Committee developed a document entitled Protocol for Assessing the Conformity of Catechetical Materials with the Catechism of the Catholic Church (USCC, 1996), and invited publishers to submit materials for review according to this protocol. Additionally, the Ad Hoc Committee undertook a feasibility study regarding the development of a national catechetical series to be utilized in Catholic schools and catechetical programs.

On June 19, 1997, Archbishop Daniel Buechlein, speaking as chair of the Ad Hoc Committee, offered an oral report on the committee's work to the general assembly of bishops. Inviting his audience to "recall that the original inspiration for the Catechism of the Catholic Church was the perceived need for a common language in service to the unity of the faith and in the global context of cultural diversity and religious illiteracy" (Buechlein, 1997, 94), he reflected on the committee's primary focus over the past year: reviewing catechetical materials to determine the extent of those materials' conformity with the Catechism. He observed that the committee had detected "a relatively consistent trend of doctrinal incompleteness and imprecision" ( 9 I4) in the materials that they had reviewed. He identified to such imprecisions:

2 In July 2001, the National Conference of Catholic Bishops (NCCB) and the United States Catholic Conference (USCC) merged to form the United States Conference of Catholic Bishops (USCCB). 
I. Insufficient attention to the Trinity and the Trinitarian structure of Catholic beliefs and teachings

2. An obscured presentation of the centrality of Christ in salvation history and an insufficient emphasis on the divinity of Christ

3. An indistinct treatment of the ecclesial context of Catholic beliefs and magisterial teachings

4. An inadequate sense of a distinctively Christian anthropology

5. A trend that gives insufficient emphasis on God's initiative in the world with a corresponding overemphasis on human action

6. An insufficient recognition of the transforming effects of grace

7. Inadequate presentation of the sacraments

8. Deficiency in the teaching on original sin and sin in general

9. A meager exposition of Christian moral life

Io. An inadequate presentation of eschatology. ( $\left.\mathbf{9} \mathrm{I}_{4}-24\right)$

In this same report, Buechlein (I997) indicated that the committee was not yet prepared to make a final recommendation regarding the feasibility of a national catechetical series.

In November 1997, speaking at the Synod for America in Rome, Archbishop Donald Wuerl of Pittsburgh, Pennsylvania, offered a short address known as an "intervention." Wuerl (1997) reiterated some of the doctrinal imprecisions Buechlein (I997) had identified and echoed the concerns of his brother bishops regarding religious illiteracy:

Religious ignorance, or, as some call it, 'illiteracy,' is a significant part of the culture with which we deal pastorally. Within the United States Catholic Conference, the bishops have attempted, through the implementation of the Catechism of the Catholic Church, to address this disquieting phenomenon by strengthening catechetical texts.... While we have worked hard to ensure the quality of religious education programs with significant effort to integrate the Catechism of the Catholic Church [sic] into all of them, nonetheless, the religious literacy level of our faithful is still a concern. (p. 435)

On September 12, 1998, Archbishop Buechlein addressed the Pastoral Congress for the Diocese of Salt Lake City. In restating the ro doctrinal deficiencies in catechetical materials he first presented in June 1997, he characterized these deficiencies as symptoms of a postmodern world unduly influenced by what Tarsitano (I998) has called the principle of plausibility. 
According to Buechlein (1998), this principle causes teachers to depict the Catholic faith in a manner inclusive of and sensitive to diverse groups of people. In the following quotation, Buechlein (1998) expressed fear that this desire to portray Catholicism in an inoffensive manner may lead teachers to dilute their presentation of Catholic truths:

Tarsitano's notion of the primacy of plausibility vis-à-vis absolute truth strikes a chord. Make no mistake, the motive of plausibility, the motive not to offend or exclude, is good and important in itself, but not at the expense of the fullness of truth. Authentic inculturation of truth cannot be achieved with plausibility as the presumed first principle.....

Surely we agree that evangelizing catechesis or preaching and also worship and prayer should not succumb to the weight of plausibility over doctrine... Yet, there is some evidence that the fullness of doctrine in the resources we use for catechesis and in preaching has suffered in recent times. ( $\Phi$ $15-16)$

Buechlein (1998) continued by theorizing that each doctrinal deficiency that he had identified in 1997 could be explained as a symptom of the postmodern world's embrace of the principle of plausibility. For example, he maintained that a postmodern concern for gender inclusivity lies at the root of the avoidance of traditional Trinitarian language, and a postmodern emphasis on community explains an ecclesiology that, in his view, overemphasizes the communal nature of the church and minimizes the magisterium.

The concern expressed by the American bishops as a whole in their 1990 document Guidelines for Doctrinally Sound Catechetical Materials, as well as by Levada (1990, 1994), Buechlein (1997, 1998), and Wuerl (1997)—prominent American Catholic leaders with deep, official ties to Rome-constitutes the broad background against which the development of the Framework is best understood. Both the bishops in general and Levada (I990, I994), Buechlein (I997, 1998), and Wuerl (1997)in particular clearly feared that doctrinally unsound or inaccurate catechetical materials would contribute to religious illiteracy among Catholics.

\section{The Framework: Initial Phases of Development}

Just four days after Buechlein's (1998) address, Archbishop Bernard Law of Boston, then a member of the Ad Hoc Committee to Oversee the Use of the Catechism, presented a report to the bishops' administrative committee 
regarding the feasibility of developing a national catechetical series to be used in all U.S. Catholic schools and parishes. Because publishers had requested that the bishops not undertake such a project, Law recommended delaying a definitive decision regarding this matter. In the meantime, the Ad Hoc Committee would continue to review materials that publishers voluntarily submitted to them for the conformity review process. In addition, Law recommended that the Committee develop "the doctrinal elements of a scope and sequence instrument" for grades nine to $\mathrm{I} 2$ in order to "assist the publishers in the development of stronger catechetical materials" "Catechism Committee Reports," I998, p. I). With the administrative committee's acceptance of this recommendation, work began on the document that would, almost a decade later, become the Framework.

In February 1999, the Ad Hoc Committee appointed a Steering Committee to coordinate the preparation of a draft of the scope and sequence instrument that Law had recommended. Serving on this committee were three priests, two laymen, and two women; six of the seven members were, at that time, on the USCC staff. The committee expressed an intent to consult with publishers "in an advisory capacity" and with other "various bodies," who were not specified ("Doctrinal Elements," I999, pp. 2-3). Within a month of its inception, the Steering Committee presented the Ad Hoc Committee with several proposed models. The model endorsed by the Steering Committee was "a comprehensive adolescent model structured on the four pillars of the Catechism [sic] which would identify doctrinal elements that an adolescent should be expected to know" (p.3).

\section{Addressing Concerns About Textbooks}

On November 15, 1999, Archbishop Daniel Buechlein, chair of the Ad Hoc Committee to Oversee the Use of the Catechism, reported to the full body of U.S. bishops gathered in Washington, DC, for their semi-annual meeting. In conducting conformity reviews of catechetical materials for, at that point, three and a half years, the committee had noted several problematic areas that surfaced repeatedly. Those areas, also communicated to publishers, were:

I. "A systematic avoidance of personal pronouns in reference to God. The practice of avoiding personal pronouns for God often led to an artificial and awkward repetition of the word God in sentences or to circumlocutions that tended to depersonalize him. We informed the 
publishers that this requirement [of using male personal pronouns in reference to God] will help to assure that as much as possible a Trinitarian theology permeates all catechetical materials" (Buechlein, I999, pp. 390-39I).

2. The use of the term "Hebrew Scriptures" instead of "Old Testament." Buechlein (I999) stated, "From a Christian perspective there are two testaments, which have been traditionally referred to as Old and New" and expressed a desire to preserve "the common language of our faith" (p. 39I).

3. The use of the abbreviations B.C.E. and C.E., designating, respectively, "Before the Common Era" and "Common Era," rather than B.C. and A.D., designating, respectively, "Before Christ," and "Anno Domini," or, in English, "Year of the Lord." Buechlein (1999) asserted that catechetical materials "should reflect that-for followers of Jesus-even time has a Christological significance” (p. 39I).

In addition, Buechlein indicated that the Steering Committee expected to have an initial draft of the scope and sequence instrument for high-school aged students by Spring 2000.

On June I5, 200I, Buechlein again reported to the full assembly of U.S. bishops, gathered for their semi-annual meeting. He expressed dissatisfaction regarding the state of adolescent catechesis in the United States, leaving open the possibility that the U.S. bishops may yet pursue the development of a national catechetical series for all U.S. Catholic secondary schools and other programs directed to adolescents:

We find that the present catechetical situation in this country on the secondary level is far from satisfactory. It is a source of concern and frustration to the Catechism Committee [Ad Hoc Committee] that, to date, the conformity review process has had relatively little effect on the catechetical materials used with a large portion of our high school age students.... The conformity listing that appears in this month's issue of Catechism Update contains the names of forty-five texts or series.... Only seven of these forty-five entries concern material for the secondary level.

Some additional conformity reviews for high school materials have taken place but the results conveyed in reports from those reviews were ignored and the publishing houses involved made the choice to release 
materials that the Catechism Committee had found unacceptable for a declaration of conformity. These materials had been judged unacceptable because they reflected many of the ten doctrinal deficiencies we had reported finding in our earlier reviews.

The Committee wants to go on record as stating that...it might be advisable for the bishops to undertake the development of a national catechetical series for Catholic high schools and/or religious education programs for older adolescents. (200I, pp. 2-3)

In November of 2002, Archbishop Buechlein was appointed chair of the United States Conference of Catholic Bishops'(USCCB) new Committee on Catechesis, which, as part of a larger restructuring of the USCCB, would now function as its own committee instead of as a subcommittee of the Committee on Education. Archbishop Alfred Hughes of New Orleans took Buechlein's place as chair of the Ad Hoc Committee. In that capacity, Hughes reported to the full body of U.S. bishops one year later, on November Io, 2003, maintaining that although some publishers were attempting to cooperate with the committee in producing texts in conformity to the Catechism, "the working relationship between the committee and some high school publishers has not yet born as much fruit as we had hoped" (Hughes, 2003, pp. 418-4I9). He stated that between March 2001 and November 2003, nearly two-thirds of the conformity reviews of high school materials resulted in a judgment of nonconformity. Moreover, these materials were deemed inadequate for revision; that is, they must be completely rewritten before being resubmitted. Hughes expressed consternation that "many of the materials found to be inadequate are still in wide use throughout the country" (2003, p. 4I9).

Hughes (2003) offered the following list of “deficiencies" (p. 4I9) identified by the Ad Hoc Committee in its reviews of materials designed for use in U.S. Catholic secondary schools:

I. A relativistic approach to the church and to faith which presented the Catholic Church as but one among equals: "Our young people are not learning what it means to say that the sole church of Christ subsists in the Catholic Church" (p. 4I9).

2. The use of "tentative language," such as "Catholics believe that..." in presenting doctrine and moral teachings: this phrasing "gives the impression that the teaching is just one legitimate opinion among others rather than a matter of truth... Our young people are not learning 
that what we know and believe is based on objective truth revealed to us by God" (p. 4I9).

3. Flawed sacramental theology in which students are taught "that the sacraments were instituted over an extended period of time, with the implication that they can still be changed" (p. 419). Hughes (2003) also maintained that some materials present the sacraments as a way to celebrate special moments in life rather than as a way to encounter Christ in a privileged way.

4. Lack of emphasis on the importance of the priesthood: "The distinctive role of the priest may be sidelined or even ignored" (p. 4I9).

5. Failure to emphasize Jesus's unique presence in the Eucharistic elements.

6. Failure to affirm the Church's teaching on the restriction of ordination to males: "The teaching about the church's prohibition on the question of the ordination of women is ambiguous or even misleading" (p. 419).

7. Use of language referring to marriage "partners" rather than to man and woman or husband and wife.

8. A perceived reluctance to identify premarital or extramarital sexual intercourse as sinful behavior: Students may be encouraged to abstain in order to avoid pregnancy or disease, but not to avoid sin.

9. Failure to treat the eschatological dimension of morality: encouraging virtue only to better oneself and the world, rather than to attain heaven or avoid hell.

Io. "A studied avoidance of revealed proper names or personal pronouns for the Persons in the Blessed Trinity. This leads to an inaccurate understanding of the divine nature of the Persons of the Trinity as well as their unity with each other and their proper relations. Some of the texts, in trying to avoid masculine titles or pronouns for the Persons of the Trinity, speak of the Father only as God and then speak of Jesus without noting his Sonship or divinity, creating an implication that Jesus is somehow different from God or even somehow less than God" (p. 4I9).

II. An unbalanced Christology, overemphasizing Jesus's humanity at the expense of his divinity.

I2. An inadequate or flawed treatment of the Holy Spirit, suggesting that the Holy Spirit is less than God. 
13. A focus on the historical-critical method of interpreting Scripture, with a corresponding failure to utilize "patristic and spiritual interpretation" (p. 4I9). Hughes maintained that the historical-critical approach obscures God's role in inspiring the Scriptures, giving the impression that these are "merely human texts" (p. 4I9).

I4. An explanation of some miracles, including Jesus's miracles, as ordinary rather than supernatural phenomena.

15. An ecclesiology overemphasizing the role of community and minimizing the role of the hierarchy.

I6. A presentation of the social mission of the Church that fails to ground this mission in God's initiative and fails to relate it to eschatological realities.

Despite this extensive, seemingly exhaustive, list of doctrinal deficiencies, Hughes (2003) stated, "This is merely a sampling of the kinds of problems that have aroused serious concerns" (p. 4I9). Therefore, Hughes (2003) urged the bishops to require that all textbooks approved for use in their dioceses carry a declaration of conformity to the Catechism. Until the approval of national doctrinal guidelines for materials used in U.S. Catholic secondary schools, he pledged that the Committee would continue to work with publishers to develop materials "that teach the faith accurately and completely" (2003, p. 420).

At this same meeting of the full body of U.S. bishops, Archbishop Buechlein (2003), chair of the new standing Committee on Catechesis, presented the proposed thematic structure of the document that would become the Framework. This structure was organized into eight parts, presumably to correspond to eight semesters of study through a four-year secondary school program. These eight parts were: basic Christology, the Paschal Mystery, the Church, Sacraments, Life in Christ (divided into two parts: personal morality and social morality), and Vocations, with the eighth part to be determined.

\section{Growing Concerns About Pedagogy}

On September 9, 2004, at the annual meeting between the Ad Hoc Committee and representatives of publishing companies, the committee urged publishers "to remind their writers and editors to make sure that catechetical materials on which they are working present the doctrine of the faith in a way that is clear, understandable and also unequivocal" ("Catechism committee holds," 2004, p. 2). In reiterating its concern regarding the "tentative manner" (p. 2) in which texts may present doctrine, the committee addressed 
"the impact that pedagogical and/or methodological approaches can have on doctrinal content" (2004, p. 2). For example, the committee urged publishers to exercise caution in developing discussion questions or reflection activities: "They [publishers] were cautioned to avoid activities which ask students to agree or disagree with doctrine or Church teaching. It was suggested that instead they ask the students the impact the particular belief or teaching can have on their own lives or the lives of others" $(2004$, p. 2).

In the summer of 2006, Archbishop Hughes (2006), chair of the Ad Hoc Committee, presented a lengthy report in Catechism Update, reflecting on the committee's work of conducting conformity reviews of textbooks over the past decade. In it, Hughes praised the bishops' "direct involvement in the preparation of catechetical materials" (2006, p. I), urging that such involvement be permanent. Hughes (2006) also traced the process by which deficiencies in secondary-level textbooks were identified, maintaining, "Naming these deficiencies proved to be a deciding moment for catechesis in this country" (pp. I-2). He then echoed the concerns expressed by the committee at its 2004 meeting with publishers by discussing a relatively recent shift in the committee's thinking regarding the relationship between content and pedagogy in Religious Studies textbooks:

When the Catechism Committee [Ad Hoc Committee] first began conducting conformity reviews, publishers were told that the review would concern only the doctrinal content and not matters of pedagogy or methodology. Gradually, the Committee recognized more clearly that some pedagogical and methodological approaches actually undermine the authentic presentation of doctrine. (Hughes, 2004, p. 3)

Hughes (2006) identified two pedagogical approaches that the Committee had deemed unacceptable. The first, rooted in a desire to avoid offending or alienating students of other faiths enrolled in Catholic schools, presented doctrine or moral teaching in a manner implying that it was simply one opinion among many legitimate views from which students may choose. Hughes stated that although textbooks espousing this approach may have explained doctrine and morality accurately, "it was done within a context which made it sound as if the doctrine was a matter of opinion and not based on truths revealed by God" (2006, p. 3). Hughes (2006) identified the second objectionable approach as "an anthropological experiential approach to catechesis" (p. 3); that is, an approach taking human experience as the starting 
point for religious education and as the lens through which religious faith and teachings may be understood. According to Hughes (2006), this methodology can lead to a subjective, relativistic presentation of faith, in which "the truth and objective reality of God's Revelation becomes blurred" (p.3).

\section{Consultation and Final Phases}

On April I, 2005, the first formal, public consultation process began on the document now carrying the working title National Doctrinal Guidelines for High School. This document refined the eight-semester program presented to the bishops in 2003 into eight topics, each of which was to comprise a one-semester course of study: Christ (Part I: The eternal word; Part II: Who is Jesus?), the Paschal Mystery, the Church, Sacraments, Life in Christ (Parts I and II), and Vocations. In the letter accompanying each U.S. bishop's copy of the document, Archbishop Daniel Buechlein, chair of the USCCB Committee on Catechesis, suggested that "consideration be given to consulting with high school religion department chairs and teachers" (personal communication, I April 2005). He also affirmed the bishops' freedom to consult with other personnel, if desired, and requested that feedback from all stakeholders be collated into a single report from the diocese to be submitted within three months: by July I, 2005. Schroeder (2013) noted that the number of dioceses responding to this appeal is unknown, as is the number of people contributing to any individual diocese's response.

The USCCB provided an "amendment form" ${ }^{3}$ for those offering feedback on the National Doctrinal Guidelines for High School. This form asked for specific words, phrases, or passages that the respondent proposed striking and for recommended new wording to replace stricken material. Respondents suggesting a new passage for inclusion were to indicate the precise location (page and line numbers) at which the new material should be inserted. Respondents were to generate multiple copies of the form so that each form would contain one comment about one specific line item. Schroeder (2013) observed that the configuration of the amendment form utilized in this first public consultation, beyond USCCB staff and consultants, did not permit comments on the eight core themes selected nor on the document's overall theological stance, thus implying that the basic structure, tone, and theological perspective of the document would remain intact in any subsequent revised versions.

3 Reproduced in Schroeder, 2013, p. 350. 
At their November 2005 and June 2006 semi-annual meetings, the bishops reviewed the comments generated during the public consultation process. Consequently, they revised the National Doctrinal Guidelines for High School to encompass six required semesters and two electives, the latter to be chosen from among five possibilities. The first six topics of the April 2005 version became the six required semesters, with some minor changes in wording; topics seven and eight became electives with three other elective topics added. The six core courses were:

I. The Revelation of Jesus Christ in Scripture (study of both Testaments)

2. Who Is Jesus Christ? (Christology)

3. The Mission of Jesus Christ (the Paschal Mystery)

4. Jesus Christ's Mission Continues in the Church (Ecclesiology)

5. The Sacraments as Privileged Encounters with Jesus Christ (Sacramental Theology)

6. Life in Jesus Christ (Morality)

The five possible elective courses were:

I. Sacred Scripture (study of both Testaments)

2. History of the Catholic Church

3. Living as a Disciple of Jesus Christ in Society (Social Justice)

4. Responding to the Call of Jesus Christ (Vocations)

5. Ecumenical and Interreligious Issues

The document urged that the six core courses be taught in the prescribed order, with the electives offered during senior year (or one each in junior and senior years).

In the spring of 2007 , the Committee on Catechesis conducted a second consultation process on the document now entitled Doctrinal Elements of a Curriculum Framework for the Development of Catechetical Materials for Young People of High School Age. As with the earlier consultation, each bishop received a copy of the revised document; any comments from the bishop and those with whom he chose to consult were to be submitted as one report to the USCCB by July I, 2007. That November, the full body of U.S. bishops, gathered in Baltimore, Maryland, for their semi-annual meeting, unanimously approved the Framework by a vote of $22 \mathrm{I}-\mathrm{O}$, with very few revisions to the draft that had been distributed the prior spring. Following this official promulgation, the document was published in print and electronic forms in July 2008. 


\section{Developments Following the Framerwork's Promulgation}

Schroeder's (2013) analysis of two key developments following the Framework's promulgation sheds light on the concrete impact the Framework may have on the Religious Studies curricula of U.S. Catholic secondary schools, particularly in dioceses in which the bishop has mandated the Framework and the exclusive use of textbooks approved by the USCCB. First, with the Framework's promulgation, publishers sought to understand the relationship between the Framework and the Protocol for Assessing the Conformity of Catechetical Materials with the Catechism of the Catholic Church (USCC, 1996). The latter document had been the tool by which all materials submitted by publishers to the bishops had been evaluated. It remained unclear whether materials intended for use in U.S. Catholic secondary schools would continue to be evaluated using the Protocols or would now be evaluated with the Framework. In April 20II, the USCCB dispelled this confusion by releasing the Secondary Level (SL) Protocol for Assessing the Conformity of Secondary Level Catechetical Materials with the Catechism of the Catholic Church (USCCB, 2orrb). Because this document presented the Framework as "the principal instrument for the review of secondary level catechetical texts" (p. 2), superseding the 1996 Protocols, textbooks designed for use in courses falling outsie the Framework's parameters will, presumably, no longer be reviewed by the bishops. Schroeder (2013) thus postulated that if a bishop mandates that all textbooks used in Catholic secondary schools in his diocese carry a declaration of conformity to the Catechism, schools may no longer offer non-Framework Religious Studies courses, such as Bioethics, Ignatian Spirituality, or Religious Themes in Film.

Secondly, in November 20II, the USCCB released Guidelines for the Treatment and the Interpretation of Sacred Scripture in Catechetical Texts (USCCB, 2orra). Within the context of emphasizing that all Religious Studies courses in U.S. Catholic secondary schools must follow the Framework's structure, this document directed that textbooks must reflect the "unity" (p. 4) of Scripture by treating both Testaments together, never separately. Because this document strongly implies that the bishops will no longer approve textbooks that focus on only the Old Testament or only the New Testament, Schroeder (2013) maintained that if a bishop mandates that schools use only USCCBapproved textbooks, schools may need to adjust their curricula to teach both Testaments in one course, or even in one semester. 


\section{Future Directions: The Need for Empirical Research}

With the 2007 promulgation of the Framework, and with the subsequent release of the Secondary Level Protocol (USCCB, 20II), the USCCB has sought to control the Religious Studies curricula of U.S. Catholic secondary schools to an unprecedented extent. Ostasiewski (2010) characterized the release of the Framework as a significant departure from the traditional role of the bishops vis-à-vis Religious Studies curricula, asserting that the Framework represents "the first time the Roman Catholic hierarchy, as opposed to individual professional religious teaching orders or publishing houses, has felt the need to step in and produce a nationwide curriculum" (p. 75). Similarly, Engel (2013) observed, "The U.S. bishops had never before specified in detail a course-by-course outline of doctrinal topics for high school" (p. 53). Given the unparalleled nature of the USCCB's actions, it seems both prudent and essential to conduct empirical research that investigates the following: the impact of the Framework on the theological content taught and on the pedagogy employed in the Religious Studies classrooms of U.S. Catholic secondary schools; Religious Studies teachers' experiences of, perceptions of, and attitudes toward the Framework; and students' perceptions of the Framework's impact on their religious knowledge and/or praxis. Schools located in dioceses that implemented the Framework soon after its promulgation have now graduated the first students to complete all of their secondary school Religious Studies courses within the Framework's structure. This pivotal moment presents a timely opportunity for both quantitative and qualitative research, before both teachers' and students' memories of their schools' pre-Framework curricula significantly diminish. Moreover, as documented by Schroeder (20I3), Religious Studies teachers have many questions regarding the Framework; such research may address these questions in a manner that productively informs these teachers' classroom praxis.

\section{Conclusion}

This article has demystified and contextualized the Framework's origins by systematically tracing its development from I985-2007, and by briefly examining two key events following its promulgation. Such information constitutes

essential background both for Religious Studies teachers charged with implementing the Framework and for researchers who may engage the Framework on multiple levels - theologically, pedagogically, and hermeneutically-and subject it to the rigors of empirical studies. Both quantitative and qualita- 
tive research, rooted in intimate familiarity with the Framework's history, has the potential to yield valuable data regarding the Framework's efficacy, particularly in comparison to schools' pre-Framework curricula. Such research, therefore, may contribute to aligning Religious Studies in U.S. Catholic secondary schools more closely with the vision that the U.S. bishops themselves put forward in their 1972 pastoral message, To Teach as Jesus Did; namely, that Religious Studies “functions as the underlying reality in which the student's experiences of learning and living achieve their coherence and their deepest meaning" ( $₫$ IO3).

\section{References}

Buechlein, D. (1997, June 19). Oral report to the general assembly of bishops, Kansas City, MO. Retrieved from http://www.usccb.org/beliefs-and-teachings/what-we-believe/ catechism/archbishop-daniel-buechlein-report-june-I997.cfm

Buechlein, D. (1998, September I2). The cultural primacy of plausibility and inculturation of our beliefs. Address to the Pastoral Congress of the Diocese of Salt Lake City, Salt Lake City, UT. Retrieved from http://www.catholicculture.org/culture/library/view.cfm?id= $656 \& \mathrm{CFID}=4237226 \& \mathrm{CFTOKEN}=\mathrm{I} 4 \mathrm{I} 99438$

Buechlein, D. (1999). Report by committee overseeing the catechism's use. Origins, 29, 390-392.

Buechlein, D. (200I, Summer). Archbishop Buechlein's report on feasibility study. Catechism Update, I-3.

Buechlein, D. (2003, November Io). USCCB report on the development of Catechisms. Oral report to the general assembly of bishops, Washington, DC. Retrieved from http:// www.catholicculture.org/culture/library/view.cfm?recnum $=5879$

Catechism committee holds annual meeting with publishers. (2004, Fall). Catechism Update, $\mathrm{I}-2$.

Catechism committee reports on feasibility study. (1998, Winter). Catechism Update, I-2

Doctrinal elements for adolescent catechesis: Tool in feasibility study. (1999, Summer). Catechism Update, $2-3$.

Engel, M. T. (2013). An analysis of Catholic high school religion textbooks based on identified methods for catechesis and taxonomies for cognitive and affective learning. (Doctoral dissertation). Retrieved from http://aladinrc.wrlc.org/bitstream/handle/196I/I4872/. Engel cua 0043A 10405display.pdf?sequence $=\mathrm{I}$

Filteau, J. (2oro, April 2). Bishops' high school catechetical guidelines work way into programs. National Catholic Reporter, $\mathrm{IA}-3 \mathrm{~A}$.

Heffern, R. (2010, April 2). Catechetical expert sees benefits, challenges with framework. National Catholic Reporter, p. 2 A.

Hudson, W. J. (2002). Window on mission: A CHS 2000 report on academic and cocurricular programs and services and religious education and formation. Washington, DC: National Catholic Educational Association. 
Hughes, A. (2003). The state of high school catechetical texts. Origins, 33, 4I7-420.

Hughes, A. (2006, July). On ten years of conformity reviews. Catechism Update, I-4.

Levada, W. (1990). Catechism of the universal church: An overview. Retrieved from http://www. usccb.org/about/evangelization-and-catechesis/an-overview.cfm

Levada, W. (1994, February 7). The new Catechism: An overview. Address at the symposium on the new Catechism, Portland, OR. Retrieved from http://web.archive.org / web/20070929103226/http://www.usccb.org/catechism/resource/lev94art.htm\#structure

Manning, P. (2012). That your education may be complete: Implementing the bishops' Curriculum Framework in continuity with the Christian teaching tradition. Catholic Education: A Journal of Inquiry and Practice, 15, 160-178.

McBride, A. (2009). A sturdy framework. America, 20I(7), r6-18.

National Conference of Catholic Bishops (1972). To teach as Jesus did: A pastoral message on Catholic education. Washington, DC: United States Catholic Conference.

O'Malley, W. (2009). Faulty guidance. America, 20I(6), I4-I6.

Ostasiewski, D. M. (2010). Looking for love: A critique of doctrinal elements of a curriculum framework for the development of catechetical materials for young people of high school age published by the U.S. Conference of Catholic Bishops (USCCB), November 2007. (Doctoral dissertation). Retrieved from http://libres.uncg.edu/ir/uncg/listing. aspx?styp $=$ ti\&id $=3668$

Raiche, D. (20I0). Assessing the impact and influence of the "high school doctrinal framework." Momentum, $4 \mathrm{I}(3), 30-33$.

Ramey, L. W. (2014). An exploration of Catholic high school Religious Studies teachers' perceptions and experiences of their role and practice (Doctoral dissertation). Retrieved from http:// repository.usfca.edu/cgi/viewcontent.cgi?article $=I I 0 I \&$ context $=$ diss

Schroeder, C. J. (2013). The U.S. Conference of Catholic Bishops' Doctrinal Elements of a Curriculum Framework for the Development of Catechetical Materials for Young People of High School Age: Pedagogical and theological perspectives of Religious Studies teachers in U.S. Catholic secondary schools. (Doctoral dissertation). Retrieved from http:// repository.usfca.edu/cgi/viewcontent.cgi? article $=1060 \&$ context $=$ diss

Tarsitano, L. (I998, January-February). Plausible missionaries. Touchstone, II(I). Retrieved from http://www.touchstonemag.com/archives/article.php?id=II-OI-OI6-f

Tiernan, P. (20I0). (Re)designing the Theology curriculum to implement the Bishops' doctrinal framework. Momentum, $4 I(4)$, 33-35.

United States Catholic Conference (1990). Guidelines for doctrinally sound catechetical materials. Washington, DC: Author.

United States Catholic Conference (1996). Protocol for assessing the conformity of catechetical materials with the Catechism of the Catholic Church. Retrieved from http://www.usccb. org/about/evangelization-and-catechesis/subcommittee-on-catechism/conformityreview/protocol-for-assessing-the-conformity-of-catechetical-materials.cfm

United States Conference of Catholic Bishops. (2008). Doctrinal elements of a curriculum framework for the development of catechetical materials for young people of high school age. Washington, DC: Author. 
United States Conference of Catholic Bishops. (201ra). Guidelines for the treatment and the interpretation of sacred Scripture in catechetical texts. Retrieved from http://www.usccb. org/about/evangelization-and-catechesis/subcommittee-on-catechism/conformityreview/upload/FINAL-Guidelines-for-the-Treatment-and-the-Interpretation-ofSacred-Scripture-in-Catechetical-Texts-II-4-II.pdf

United States Conference of Catholic Bishops. (20mb). Secondary level (SL) protocol for assessing the conformity of secondary level catechetical materials with the Catechism of the Catholic Church. Retrieved from http://www.usccb.org/about/evangelization-andcatechesis/subcommittee-on-catechism/conformity-review/upload/part-i-protocoland-introduction.pdf

Western Catholic Educational Association (2013). Ensuring Educational Excellence (E3). Retrieved from http://westwcea.squarespace.com/documents/secondary-documents

Wuerl, D. (1997). Renewing catechesis redounds to social order's benefit. Origins, 27, 434-435.

Zapor, P. (2008, January 2I). Bishops approve curriculum framework for catechesis of high school students. The Catholic Voice. Retrieved from http://www.catholic voiceoakland. org/2008/o8-oI-2I/inthisissuerz.htm

Carrie J. Schroeder, M.Div., Ed.D., is the Director of Campus Ministry at Mercy High School in San Francisco, CA and a graduate of the University of San Francisco's Doctoral program in Catholic Educational Leadership. Correspondence regarding this article may be addressed to cschroeder@mercybs.org. 